\title{
NORWID W BADANIACH ROLFA FIEGUTHA
}

\author{
VADE-MECUM - „POEZJA W FAZIE KRYTYCZNEJ” \\ W PERSPEKTYWIE KOMPARATYSTYCZNEJ \\ „KONFRONTACJI MIĘDZYKULTUROWEJ”
}

Któż spośród norwidologów nie czytał studium Rolfa Fiegutha o ,poezji w fazie krytycznej", poświęconego Vade-mecum? Znamy je wszyscy, przed laty opublikowane w jednym z pierwszych numerów rocznika „Studia Norwidiana” (3-4: 1985-1986) ${ }^{1}$, nadało potem tytuł zbiorowi rozpraw z literatury polskiej wybitnego, niemieckiego slawisty ${ }^{2}$. Autor wspomnianego studium wkroczył do polskiego kręgu badań norwidologicznych, by tak rzec, krokiem zamaszystym, wszak wspomniany numer „Studiów” rozpoczynał tekst przetłumaczonej na język polski przedmowy Hansa Roberta Jaussa do pierwszego niemieckiego wydania $\mathrm{Va}$ de-mecum w przekładzie Fiegutha (Monachium, 1981)3. Recenzję tego przekładu pióra Andrzeja Vincenza przynosił wcześniejszy numer „Studiów” (2: 1984) Vincenz zwracał uwagę na znaczenie przedmowy Jaussa, zwłaszcza na przyzna-

1 R. Fieguth, Poezja w fazie krytycznej. Cykl wierszy Cypriana Norwida „,Vade-mecum”, „Studia Norwidiana” 3-4: 1985-1986, s. 13-55.

2 R. Fieguth, Poezja $w$ fazie krytycznej i inne studia z literatury polskiej, Izabelin 2000, ss. 327 .

${ }^{3}$ H. R. JAuss, Przedmowa do pierwszego niemieckiego wydania ,,Vade-mecum” Cypriana Norwida, s. 3-11. W rzeczywistości to pierwsze niemieckie wydanie Vade-mecum było dwujęzyczne, polsko-niemieckie: C. Norwid, Vade-mecum. Gedichtzyklus (1866). Polnisch und deutsch, Mit einer Einfürhung von H.R. Jauss, Eingeleitet und übersetzt von R. Fieguth, München 1981.

${ }^{4}$ A. Vincenz, Norwid po niemiecku, „Studia Norwidiana” 2: 1984, s. 84-90. 
ne w niej cyklowi poetyckiemu Norwida prawo do zajęcia należnego mu miejsca w kanonie dzieł literatury światowej.

Podobna intencja odnalezienia miejsca autora Vade-mecum w szerokiej panoramie prądów i nurtów poezji towarzyszy Fieguthowi, który w swych studiach nad Norwidem przyjął strategię zgoła odwrotną od prowadzonych równolegle studiów na Mickiewiczem. Jego Mickiewicz jest przedstawicielem literatury światowej, ale tajemnicy wielkości autora Ballad i romansów niemiecki slawista szuka w podejściu polskiego poety do rodzimej tradycji literackiej, wskazując na ciąg nawiązań do poezji mistrzów renesansu, baroku i oświecenia ${ }^{5}$. W przypadku badań nad Norwidem zachęcał natomiast konsekwentnie do wyjścia z polskiego partykularza. Służyły temu w przywoływanym studium o Vade-mecum nowe założenia lektury tego cyklu wierszy Norwida, które sytuowały je w „fazie krytycznej” dziejów poezji europejskiej. Nie oznaczało to wcale odwrócenia się od kontekstów literatury polskiej, zwłaszcza w perspektywie przyszłych jej dziejów, dla których Norwid pełnił swą twórczością rolę antycypującą.

Fieguth stale w swym studium podkreśla wielogłosowy dyskurs poezji Norwida z poezją - europejską i polską. Najważniejsze założenie lektury Vade-mecum to rozpoznanie w tym zbiorze wierszy wczesnego przejawu rozumienia współczesności. Stąd tylko krok do stwierdzenia, że dwudziestowieczna współczesność wyrasta z wieku dziewiętnastego, na drodze normalnej ciągłości historycznej. Badacz wskazuje na postępujące od lat sześćdziesiątych dwudziestego wieku zacieranie się cezury pomiędzy „tradycją a nowatorstwem” i rosnące poczucie niemal nieprzerwanego związku z dziewiętnastowieczną przeszłością. W tezie Juliusza Wiktora Gomulickiego o analogii pomiędzy Vade-mecum a Kwiatami zła odnalazł niemiecki slawista argument pozwalający wysunąć Norwida na pierwsze miejsce w procesie narodzin nowoczesnej liryki polskiej i europejskiej. To zestawienia tych dwóch zbiorów poezji prowadzi też do docenienia ich cyklicznej budowy, w jej analizie Rolf Fieguth jest prawdziwym mistrzem. Także inne studia dotyczące cykliczności w poezji Kniaźnina ${ }^{6}$, czy Mickiewicza ${ }^{7}$ świadczą o tym, że autor studium o „poezji w fazie krytycznej” ma własną koncepcję badań cykli po-

5 Teza, że, ,jedną z tajemnic sukcesu Mickiewicza od jego wczesnych lat było ożywienie polskich tradycji literackich” została konsekwentnie udowodniona w książce Rozpierzchłe gałąki. Cykliczne i skojarzeniowe formy w twórczości Adama Mickiewicza, przeł. M. Zieliński, Warszawa 2002. Pierwsze wydanie niemieckojęzyczne: Verzweigungen. Zyklische und assoziattive Kompositionsformen bei Adam Mickiewicz, Freiborg Schweiz 1998.

${ }^{6}$ R. Fieguth, ,, Sobie wielki”. O pięciu zbiorach lirycznych Franciszka Dionizego Kniaźnina, Warszawa 2018 (tu zwłaszcza rozdział: O cyklu ,Erotyki”, s. 59-123).

${ }^{7}$ Rozpierzchte gałazki. 
etyckich, która w proponowanej przez niego lekturze Vade-mecum akcentuje gatunkowy sens cykliczności tego zbioru wierszy.

Tytuł swego studium o ,poezji w fazie krytycznej” zawdzięczał jego autor pamiętnej frazie ze wstępu Do czytelnika, która poprzedza Vade-mecum: „poezja polska [...] znajduje się w krytycznej chwili" i do której Fieguth nawiązuje, stwierdzając: „,sam cykl został tu pomyślany jako wyraz świadomości kryzysu poezji i jako krytycznego obrachunku z poezją i z epoką - właśnie jako «poezja w fazie krytycznej»"

Zdaniem badacza ów krytyczny obrachunek z poezją i epoką decyduje o koncepcji języka poetyckiego Norwida, określa nie tylko program jego poezji, ale decyduje o sposobie poezjowania, przesądza o budowie poszczególnych wierszy i organizacji całego cyklu - bodaj czy nie najważniejsze to założenie lektury. Niemiecki slawista stwierdza:

Zarówno znaczeniową organizację poszczególnych jego utworów, jak i - w wypadku Vademecum - metodę ich zestrojenia w całość cykliczną znamionuje ironia, sprzeczności, niekoherencje, niejasności, przemilczenia, zagęszczenia semantyczne, wieloznaczności i niejednorodność stylu. Funkcja tych strukturalnych właściwości cyklu staje się zrozumiała wówczas dopiero, gdy spojrzymy na nie przez pryzmat licznych tu (często krytycznych) nawiązań do innych, dawniejszych i współczesnych programów artystycznych i poetyckich, jak również w świetle przenikającego to dzieło namiętnego rozrachunku z epoką i moralistycznego patosu. Ujrzane z tej perspektywy, rysują się one jako wyraz takich koncepcji poezji, która jawi się nie w postaci zamkniętego systemu, lecz jako faza przejściowa, ogniwo nigdy nie kończącego się, uwikłanego w dzieje polityczne i społeczne historycznopoetyckiego procesu r o z w o j o w e g o, sięgającego jednym biegunem w głęboką przeszłość [...], drugim zaś wybiegającego w przód $[\ldots]^{9}$.

Autor tych słów akcentuje przede wszystkim znaczenie sił odśrodkowych w porządkowaniu (a raczej nieporządkowaniu) wierszy cyklu, prowadzących do niekoherencji kompozycyjnej nie tylko w obszarze całego cyklu, także w obszarze poszczególnych utworów. Koncentruje uwagę na procesach zachodzących w materii powstającego wiersza, które wprowadzają język poezji w stan zakłóceń - sprzyjają temu neologizmy, niezdarne konstrukcje gramatyczne, interpunkcyjna rozrzutność, ,wywrotowa” wielostylowość, mieszanie toku monologowego z dialogowym. Wywoływanym zakłóceniom nie przeciwdziała, w tym sensie, że ich nie koryguje, wyczuwalna obecność - jak to Fieguth ujmuje - ,ironicznej bądź przenikliwej intencji osobowości stojącej za całością dzieła" ${ }^{10}$. Jest ona skie-

\footnotetext{
8 R. Fieguth. Poezja w fazie krytycznej, s. 15, przypis 8.

9 Tamże, s. 16.

10 Tamże, s. 38.
} 
rowana przeciwko stereotypowi poety natchnionego, wyraża zwątpienie twórcy w samego siebie, jak w wierszu Bliscy:

Więc gdy na chustki ostatniej już brzegu

Łzy ślad spełznie swym ostatkiem;

Więc gdy ostatni z przyjaciół szeregu

Wspomni Cię j u ż, j u ż przypadkiem --

Wtedy o! Wtedy - myśl i życia watek,

I ślad dramatyczny bytu

Twego, w swej wtóry wnikłszy od-początek,

Zbudzi się Tobą do sytu.

Bo teraz wszędzie jeszcze Twoje nie ja

Obejmać musisz sumieniem;

I nie Twój jesteś rozum i nadzieja,

I jesteś Twoim zwątpieniem!

(PWsz II, 75-76)

W analizie języka i konstrukcji podmiotu lirycznego w Vade-mecum autor omawianego studium jest niezwykle rzetelny i wnikliwy, jego teza o celowych zakłóceniach w komunikacji sensu poszczególnych wierszy jest wynikiem ich analiz, wchodzenia w głąb struktury poetyckich wypowiedzi, zwłaszcza w przypadku fragmentów następujących utworów: Do Walentego Pomiana Z., Wieś, Obojętność, Cenzor-krytyk, Królestwo, Idee i prawda, Kolebka pieśni, Dwa guziki (z tyłu), Cacka, Klaskaniem mając obrzękłe prawice, Przeszłość, Coś, Jak, Ironia, Socjalizm, Sieroctwo, Krytyka. I przytoczonego fragmentu wiersza Bliscy.

Fieguth wskazuje na paralelę dla swych analiz w pracach Romana Jakobsona, dotyczących ,poezji gramatyki”, zwłaszcza w znanym szkicu o wierszu Czułość ${ }^{11}$. Można by rozszerzyć tę analogię na strukturalistyczne podejście do poezji Norwida w badaniach Michała Głowińskiego, który w swym klasycznym już dziś artykule Norwida wiersze-przypowieści ${ }^{12}$, wskazywał na rodzaj poetyki archaicznej stosowanej przez autora Vade-mecum, która powodowała kłopot z odbiorem poezji przez dziewiętnastowiecznego czytelnika, oddalone-

11 R. Jakobson, „Czułośc”” Cypriana Norwida, w: For Wiktor Weintraub. Essays in Polish Literature, Language and History. Presented on the Occasion of His 65th Birthday, The Hague 1975, s. 227-237.

${ }_{12}$ M. GŁowIŃsKi, Norwida wiersze-przypowieści, w: Cyprian Norwid. W 150-lecie urodzin poety. Materiały z konferencji naukowej. 23-24 września 1971, red. M. Żmigrodzka, Warszawa 1973. 
go w czasie od kultury dawnych epok w literaturze, promujących gatunki alegoryczne. Bliski rozpoznaniu Fiegutha o poezji zakłóceń w Vade-mecum byłby Głowiński zwłaszcza w swej interpretacji wiersza Purytanizm, w której podnosząc znaczenie „wirtuozowskiej gry językowej”, łączy Norwida z poezją lingwistyczną dwudziestego wieku. Tym, co ten rodzaj gry z językiem umożliwia jest zdaniem interpretatora konwencja poematu dygresyjnego. Główną tezą tego szkicu jest przekonanie, że:

związki z poetyką poematu dygresyjnego ujawniają się u Norwida nie tylko w kilku większych utworach, ich domeną są również, a może przede wszystkim, utwory drobne, w tym także sporo wierszy wchodzących w skład Vade-mecum, utwory, do których nie można było przenieść całej narracyjnej machiny, właściwej tego typu romantycznym poematom, można zaś było przejmować - i przez nowe ujęcia nadawać nowe sensy ${ }^{13}$.

Obaj badacze odsłaniają w swych analizach i interpretacjach estetykę fragmentaryczności w poezji Norwida, a także żywioł ironii, wyrażającej stosunek poety do świata, w którym zapanował chaos. Różnica pomiędzy ich rozpoznaniami dotyczy kompetencji podmiotu lirycznego - według Głowińskiego ów podmiot jawi się jako wirtuoz, manifestujący swe bezwarunkowe panowanie nad językiem poetyckim. Zdaniem Fiegutha mamy do czynienia z manifestacją ograniczeń sprawności językowej podmiotu, który często w analizowanych wierszach Vade-mecum posługuje się ,stylem nijakim”, umożliwiającym programowe odejście od ideału artystycznej perfekcji językowej.

Wydaje się, że najbliższy w swych obserwacjach działania reguły świadomej dysharomonii w poezji Norwida byłby niemiecki slawista ustaleniom Zdzisława Łapińskiego, mam tu na uwadze przede wszystkim następujący fragment jego rozważań:

Norwid, tasując i odrębnie dawkując określone tradycje rodzajowe, wywoływał w utartej wrażliwości artystycznej poczucie niekongruencji. I o ile większość jego poprzedników kusiła się o wytworzenie nowej zasady unifikującej - to Norwid tę niekongruencję manifestował. Była ona bowiem środkiem rozładowywania, nie zaś wznoszenia na nowo - wizji monolitycznej. Dzięki temu uczucia w utworze wyrażane - zyskiwały wartość dramatyczną, zaś myśli w nim poddawane - zyskiwały wielostronność ${ }^{14}$.

${ }_{13}$ M. GŁowIŃSKI, Gorzkie kalambury. O „Purytanizmie” Cypriana Norwida, „Studia Norwidiana” 2: 1984, s. 73.

${ }^{14}$ Z. ŁAPIŃSKI, Norwid, Kraków 1984, s. 35. Łapiński trafnie zauważa, że zasada łączenia sprzecznych elementów w poezji Norwida ma swój długi stan badań, wskazuje przy tym na stanowisko Wacława Borowego (tegoż, O Norwidzie, Warszawa 1960, s. 7-24). 
Fieguth, podobnie jak inni badacze języka poetyckiego Norwida, zwraca uwagę na kluczowe znaczenie przekonania poety, że doskonała liryka musi zachowywać skazy, których poecie nie wolno wygładzać. Autor rozprawy o, ,poezji w fazie krytycznej" wiąże te skazy z charakterem epoki, w której powstał cykl Vade-mecum, znajduje uzasadnienie dla cech tego zbioru poezji w kształcie i odmianach czasu, w poszczególnych wierszach przybierają one postać czasu zniekształconego, przerwanego, niekiedy zniszczonego. Sądzić można, że ten topos czasu zniszczonego jest pochodną przedstawianej rzeczywistości, jej cechą ontyczną („Ironia jest bytu cieniem").

Epokę ,poezji w fazie krytycznej” badacz sytuuje historycznie i biograficznie zarazem, nawiązując do miejsc pobytu poety, co wprost wyraża w stwierdzeniu:

Jego liryka budzi nasze zainteresowanie jako swoista odpowiedź na problemy epoki, na proces kształtowania się industrialnego społeczeństwa masowego, którego skutków Norwid doświadczał w Nowym Jorku, Londynie, zwłaszcza zaś w Paryżu Drugiego Cesarstwa ${ }^{15}$.

Niewątpliwe ten punkt widzenia bliski jest znanej tezie Zofii Stefanowskiej wyrażającej się w tytułowej formule ważnego dla norwidologii artykułu Norwid-pisarz wieku kupieckiego i przemysłowego ${ }^{16}$. Autorka tego artykułu pisała:

Po klęsce Wiosny Ludów musiały się rozsypać mury polskiego getta w Paryżu i nieuchronnym biegiem rzeczy straciła podstawę absolutyzacja sprawy narodowej. Reprezentant drugiego pokolenia emigracji, Norwid, zaczął żyć jako obywatel dwumilionowej metropolii, jako uczestnik dziewiętnastowiecznych procesów cywilizacyjnych. Romantyczność jego była rezultatem ścierania się tych wyobrażeń, które świadomości polskiej narzuciło pokolenie Mickiewicza, z tymi wyobrażeniami, które były kształtowane przez długie lata paryskiego życia ${ }^{17}$.

Można by rzec, że Fieguth pyta o konsekwencje takiego usytuowania Norwida w czasie, o konsekwencje dla jego twórczości kształtowanej w społeczeństwie cywilizacji przemysłowej. Odpowiedzi jakich udziela dotyczą wielu aspektów życia i twórczości poety. Przede wszystkim poszerza pole pokoleniowych relacji - przedstawia Norwida jako rówieśnika Gustawa Flauberta (1821-1880) i Charlesa Baudelaire'a (1821-1867), ale także Gotfryda Kellera (1819-1830), Conrada Ferdynanda Meyera (1825-1898) oraz Mikołaja Niekrasowa (1821-1878) i Fio-

15 R. Fieguth, Poezja w fazie krytycznej, s. 15.

16 Z. STEFANOWSKA, Norwid - pisarz wieku kupieckiego i przemysłowego, w: Literatura, komparatystyka, folklor. Księga pamiątkowa poświęcona Julianowi Krzyżanowskiemu, red. M. Bokszczanin, S. Frybes i E. Jankowski, Warszawa 1968, s. 423-460.

17 Tamże, s. 456. 
dora Dostojewskiego (1821-1881). Jakże inna konstelacja pisarzy od tej, do której przyzwyczaił nas Kazimierz Wyka wyróżniający drugą generację romantyków w literaturze polskiej - twórców urodzonych w początku lat dwudziestych dziewiętnastego wieku ${ }^{18}$. Inna też od tej związanej z przynależnością Norwida do tzw. Cyganerii Warszawskiej, którą tak wnikliwie scharakteryzowała Zofia Trojanowiczowa $^{19}$. Takie poszerzenie pokoleniowego kręgu poety ma uzasadnienie zwłaszcza wtedy, gdy chcemy - jak pisze Fieguth - zastąpić autora Promethidiona - autorem Vade-mecum. Niemiecki slawista odnosi się w tym fragmencie swych rozważań do podejmowanych w polskiej krytyce literackiej, zwłaszcza przez Juliana Przybosia, prób odkrycia nowoczesności poezji Norwida, prowadzących do przemiany jego obrazu, w którym ,w miejsce kontrowersyjnego < poety-filozofa> zaczęła się wyłaniać sylwetka prekursorskiego liryka"20.

Przekraczanie progu poezji narodowej w lekturze Vade-mecum odbywa się bez unieważniania go, tyle tylko, że Fieguth sięga po polską poezję przyszłości, niejako przez Norwida (jak twierdzi) zapowiadaną - poezję Tuwima, Iwaszkiewicza, Wierzyńskiego, Miłosza, Baczyńskiego, Różewicza, Herberta. I co osobliwe - Białoszewskiego, pomimo jego „samodzielnego rodowodu” (jak pisał o nim Wyka, na którego się Fieguth powołuje). Przyznać trzeba, że to wybieganie z Norwidem w przyszłość, w poezję dwudziestego wieku, potwierdziło się w jej dalszych badaniach, wydaje mi się jednak, że najbardziej odważną formułę obecności autora Vade-mecum wypowiedział Stanisław Barańczak w szkicu Norwid: obecność nieobecnego ${ }^{21}$.

Autor omawianego studium większą wagę przywiązuje do kontekstów europejskich Vade-mecum, łącząc swą refleksję na ten temat $\mathrm{z}$ od dawna obecną w polskiej krytyce literackiej tezą o uniwersalizmie poezji Norwida. Stwierdza, że

[...] wpisana w Vade-mecum perspektywa dziejów poezji zupełnie otwarcie obejmuje dziedzictwo europejskiej literatury, sztuki i filozofii. Przywołują je wielkie imiona i nazwiska: Orfeusza, Homera, Dawida, Ezechiela, Jeremiasza, Ajschylosa, Sokratesa, Platona, Fidiasza, Cycerona, Horacego, Wergiliusza, Dantego, Tassa, Kochanowskiego, Szekspira, Woltera, Koźmiana, Byrona, Mickiewicza, Słowackiego, Bérangera, Musseta, Chopina; pewne zaś pośrednie przesłanki zdają się wskazywać szereg dalszych $[\ldots]^{22}$.

18 K. WYKa, Pokolenia literackie, przedmowa H. Markiewicz, Kraków 1977, s. 249-306.

19 Z. Trojanowicz, Rzecz o młodości Norwida, Poznań 1968, s. 9-116.

20 R. Fieguth, S. 23.

${ }^{21}$ S. BARAŃCZAK, Norwid: obecność nieobecnego, w: tenże, Tablica z Macondo. Osiemnaście prób wyttumaczenia, po co i dlaczego się pisze, Londyn 1990, s. 89-105.

${ }^{22}$ R. Fieguth, s. 17. 
Czy ciągi tradycji, które Fieguth odnajduje w zbiorze wierszy Norwida są wyrazem jakiejś pełni reprezentacji europejskiego dziedzictwa? Z pewnością bliskie jest mu przekonanie wyrażone w przeszłości przez pierwszego monografistę $\mathrm{Va}$ de-mecum, Zdzisława Jastrzębskiego o tym, że zbiór ten to summa poetica. Niemiecki slawista wie też nadto dobrze, iż owe ciągi tradycji polegają jednak na wyborze, wyborze - dodajmy - asystemowym. I że nie wszystkie elementy tego wyboru odgrywają równie ważną rolę.

Kwestię tę podjął na nowo w szkicu „Vade-mecum” Cypriana Norwida w kontekście Wiktora Hugo i Charles'a Baudelaire'a opublikowanym po polsku w tomie rozpraw zatytułowanych Gombrowicz z niemiecka gęba i inne studia komparatystyczne ${ }^{23}$. Całej tej książce przyświeca jasno w niej skrystalizowana koncepcja komparatystycznej „konfrontacji międzykulturowej”, która wykracza poza dualne ujęcia twórczości literackiej, odsłaniając zawsze szeroki, europejski kontekst spotkań poetów i ich tekstów uczestniczących w procesie przenikania się kultur narodowych. W zastosowaniu do Vade-mecum koncepcja ta okazała się szczególnie trafna, pozwoliła oprócz zwykle przywoływanej w omówieniach tego cyklu wierszy tradycji epickiej (Odyseja i Boska Komedia), zapytać o współczesne Norwidowi odniesienia. I to wykraczające poza często przeprowadzaną analizę porównawczą z Kwiatami zła Baudelaire'a. Fieguth przekonująco argumentuje, że Vade-mecum i Kwiaty zła są twórczą opozycją wobec poezji Victora Hugo, zwłaszcza w sferze kompozycyjnego uporządkowania wierszy w większą całość. Badacz zwraca uwagę na to, że znajomość twórczości Hugo została przez Norwida potwierdzona, natomiast znajomość Baudelaire'a nie jest udokumentowana. Analizy Fiegutha odkrywają aluzje i nawiązania w twórczości Norwida do Hugo jako głównego reprezentanta francuskiej kultury literackiej, pisarza, który odniósł ogromny sukces, a dla polskiego poety, dotkniętego tragedią twórcy nieznanego, stał się uosobieniem próżnej sławy. Autor przywołanego tu szkicu stwierdza:

Z całą pewnością Norwid widział poetę francuskiego między innymi jako reprezentanta ery „panteizmu-druku” oraz „czytania pędem” (I.Vade-mecum), jako jednego z autorów, którzy dziś , są jak Bóg”, gdyż „dość jest, że tchną, wnet arcydzieło wstawa” (LXI. Bogowie i człowiek), oraz za jednego z najbardziej typowych nosicieli sukcesu, który „bożkiem jest dziś” $(\text { LXXXVII. Omytka })^{24}$.

${ }^{23}$ R. Fieguth, „Vade-mecum” Cypriana Norwida w kontekście Wiktora Hugo i Charles'a Baudelaire'a, w: Gombrowicz z niemiecka gęba i inne studia komparatystyczne, Poznań 2011, s. 246-261.

24 Tamże, s. 250. 
Ale nie znaczy to wcale, że nie ma pomiędzy polskim i francuskim poetą cech wspólnych dotyczących ich twórczości, Fieguth niektóre wylicza: „wyraźny temperament publicystyczny, zmysł historyczny, wrażliwość na tematy z dziedziny muzyki i sztuk pięknych, głęboka świadomość historycznoliteracka i religijna, a także fascynacja Byronem" 25 . Mnożąc podobieństwa i kontrasty pomiędzy koncepcjami uprawiania poezji przez Norwida i Hugo, niemiecki badacz zwraca przede wszystkim uwagę na to, że obaj zmagali się z dziedzictwem gatunkowym dawnego poematu, którego ramy organizowały w ich twórczości większe zespoły wierszy w pewnego rodzaju narracyjne całości, jak w przypadku Legendy wieków i Vade-mecum. Fieguth słusznie podkreśla bark szerszych opracowań tej zbieżności w dotychczasowym stanie badań. I próbuje tę lukę wypełnić, przyznać trzeba, że z dużym sukcesem. Charakteryzując sfery zbieżności i odmienności wspomnianej Legendy wieków w porównaniu do Vade-mecum, rozbija tę dualną analizę odnosząc oba zbiory wierszy do Kwiatów zła Baudelaire'a i odkrywa w ten sposób polemiczne nastawienie Kwiatów zła i Vade-mecum wobec typu cyklicznej kompozycji Hugo. Cykle Norwida i Baudelaire'a nie są, w odróżnieniu od cyklu Hugo, prowadzone spójną liną narracyjną, a czytelnik, pozostając zdany na samego siebie, współtworzy w akcie interpretacji sens opowieści.

Warto zauważyć, że w swych analizach analogii pomiędzy Vade-mecum a Kwiatami zła Fieguth dystansuje się od silnie zadomowionego w polskim stanie badań przekonania o tym, że cykl wierszy Baudelaire'a miałby być źródłem inspiracji dla cyklu wierszy Norwida, poprzestaje na przekonującej konkluzji: „z europejskiego punktu widzenia oba cykle należą do tej samej sytuacji historycznopoetyckiej. Nie musimy tu nawet przypuszczać, że Norwid swoim $V M$ świadomie i celowo chciał wdać się w literacką polemikę z cyklem Francuza, jak sugeruje Juliusz Wiktor Gomulicki”" ${ }^{26}$. Autor tych słów sądzi, iż oba cykle mogą niezależnie od siebie nawiązywać do Boskiej Komedii. Wskazuje też na polską tradycję ,,setnika" wierszy duchowych, jako prawdopodobne źródło natchnień dla Norwida.

Gdybym miał wskazać na konsekwencje przyjętych założeń w podejściu do Vade-mecum przez Rolfa Fiegutha, to przypominając tu wcześniejszą tezę o „poezji w fazie krytycznej", zwróciłbym uwagę, że najsilniej z nią koresponduje w omawianym szkicu fragment poświęcony Fortepianowi Szopena, jako temu ogniwu cyklu, które najlepiej zaświadcza o tendencji destrukcyjnej w kompozycji cyklu. Badacz ma tu na myśli zarówno cechy formalne tego utworu, który swą formą rozbudowanej (fragmentarycznie dziwnej) ody rozsadza kompozycję cy-

\footnotetext{
25 Tamże, s. 252.

26 Tamże, s. 244.
} 
klu, jak i symbol roztrzaskanego fortepianu Szopena, wyrażającego akt zniszczenia doskonałości sztuki.

\section{ZAPROSZENIE DO QUIDAMA}

Wtajemniczenie Rolfa Fiegutha w poezję Norwida przebiegało w odwrotnym porządku niż ten związany z jej chronologicznym rozwojem, oznaczało przejście od Vade-mecum do Quidama. A to stworzyło okazję do przeprowadzenia korekt w projekcie badań. Rzymski poemat sprzyjał temu, by więcej uwagi poświęcić tematowi chrześcijańskiemu w twórczości poety, o czym wprost mówi autor książki Zaproszenie do „Quidama” "27. Ale to nie jedyna odmiana, najważniejszą cechą studiów pomieszczonych w tej książce jest ich monograficzny charakter, przyświecający autorowi zamiar całościowego ujęcia problemów badawczych przypowieści o losach Aleksandra z Epiru. Studia te powstawały latami, w formie odczytów i publikacji wieńczących konferencyjne spotkania poświęcone Norwidowi. Wszystkie je łączy zamiar przezwyciężenia trudności w lekturze poematu, odnotowywanych od samego początku jego recepcji. Można by powiedzieć, że wzięły się z czytelniczego entuzjazmu niemieckiego slawisty, zauroczonego dziełem Norwida. I umiejącego już obcować z nim jako dobrze rozpoznanym wcześniej autorem Vade-mecum.

Fiegutha zachwyca przede wszystkim to właśnie w Quidamie, co czyni jego lekturę trudną: rzekomo nieprzydatne metafory, porównania i dygresje, rozbicie arbitralnie pomieszanych wątków, nieprzejrzyste traktowanie czasu. To zapowiada późniejsze eksperymenty ,poezji w fazie krytycznej”. Ale entuzjazm badacza ma też swe źródło w genezie samego poematu, niemiecki slawista twierdzi, że utwór ten został napisany „w autorskiej radości”. I zwraca uwagę, że „język skrzy się pomysłowością, dowcipem, humorem" ${ }^{28}$. Czyni wiele, aby przekonać zainteresowanych poznaniem poematu Norwida, że w akcie lektury rozkosz obcowania $\mathrm{z}$ tekstem przeważa nad męką czytelniczą. $Z$ tego też wzglądu koncentruje uwagę na tematyce erotycznej utworu, związanej z postaciami Elektry-diwy i Zofii z Knidos, zwłaszcza eksponowanie „seksualnej strony Zofii” - jak pisze badacz - idzie pod prąd całej tradycji odczytywania tej postaci. Eksponowanie wątków erotycznych wiąże się też w tej lekturze z założeniem eksplikowanym na wstępie:

27 R. Fieguth, Zaproszenie do „, Quidama”. Portret poematu Cypriana Norwida, Kraków 2014, zob. przypis 13, s. 21.

${ }_{28}$ Tamże, s. 8. 
Claudio Abbado, włoski dyrygent, powiedział kiedyś, że utwór muzyczny, który przygotowuje do wykonania pod swoją batutą, musi w pierwszej kolejności pokochać. Chciałbym tę zasadę zastosować do niniejszej książki o Quidamie Norwid, zwłaszcza dlatego, że poemat ten, jak wiadomo, opiera się łatwym zachwytom ${ }^{29}$.

Gdybym miał wskazać najważniejsze kierunki tej rozwijającej się miłości Rolfa Fiegutha do rzymskiego poematu, to wskazałbym - po pierwsze - uroki świata zewnętrznego, po drugie - tajemnicę alegorezy i religijności, po trzecie - formułę Norwidowskiego klasycyzmu. To są najważniejsze dominanty tematyczno-problemowe, wokół których niemiecki slawista komponuje ,portret” Quida$m a$, a już samo to zapożyczenie części tytułu ze sztuki malarskiej jest dowodem wielkiego podziwu dla sztuki poetyckiej Norwida i chęci przedstawienia jej nieprzemijających walorów.

Odkrywaniu uroków świata zewnętrznego towarzyszy Goethe ze swoją maksymą „Poezja na swym najwyższym szczycie świeci cała zewnętrznością”, która zachęca do odwagi odkrywania naoczności i tego co konkretne. Fieguth proponuje zatem odwrotny od ustalonego porządek lektury, zwykle podążano za genologicznym sygnałem przypowieści, koncentrującym uwagę na filozoficznym przesłaniu utworu. Przywołajmy chociażby jedno spośród istotniejszych świadectw dawniejszej lektury Quidama, książkę Ewy Bieńkowskiej Norwid-Nietzsche. Dwie twarze losu ${ }^{30}$. Niemiecki slawista zaprasza nas do Quidama nie wahając się studiować reżyserii światła słonecznego w poemacie, jakby w opozycji do ugruntowanego w stanie badań przekonania, jakoby większość akcji odbywała się w godzinach wieczornych. Koncentruje też uwagę na gestach, pozach i mowie ciała bohaterów utworu, zajmuje go to bardziej niż dociekanie ich głębi myślowej. Gesty uwodzenia i miłości Elektry i Luciusa oraz gesty zdradzające subtelne relacje między Aleksandrem a Zofią, gesty indywidualnej i zbiorowej mowy ciała zastępują często w analizach badacza słowo, czy też dialog, który nie zostaje przytoczony w sytuacjach komunikacji międzyludzkiej. Rozbudowana mowa ciała często też jednak pozwala mu rozumieć skomplikowane komentarze poety do przedstawianych w poemacie sytuacji. To analiza gestów pozwoliła wydobyć znaczenie fizycznej siły Aleksandra, który góruje swą postacią nad innymi. I analiza gestów odbiera pewność siebie cesarzowi Hadrianowi. Fieguth cały czas pamięta o zachwycie tą gestyczną stroną dziania się poematu, odkrywa piękno gestu, zwłaszcza w przypadku portretu zbiorowego, jak w charakterystyce Maga Jazona upodobnionego do ruin narodu żydowskiego. Z śledzenia gestów też wnosi o wyreżyserowanym przez poetę upodobnieniu zachowań niektórych bohaterów

29 Tamże, s. 17.

30 E. BIEŃKOWSKA, Norwid-Nietzsche. Dwie twarze losu, Warszawa 1975. 
do Chrystusa, tak tłumaczy działanie zasady imitatio Christi w przypadku krwi pieczętującej kolana tych, którzy przyglądają się śmierci Aleksandra.

Analiza gestów zaprasza badacza Quidama do religijnego świata poematu, w którym najważniejszym ośrodkiem wydaje się Aleksander jako projekt człowieka idealnego. „Będę dowodził - stwierdza Fieguth - że Norwid projektuje w tej postaci człowieka idealnego, skazanego na doczesną porażkę, ale zapowiadającego lepszą przyszłość w historii człowieczeństwa, kiedy »chrześcijaństwo w zupełności rozbłyśnie«"31. Ten zamiar powiódł się całkowicie, a te fragmenty książki, które dotyczą tzw. człowieka idealnego należą do najbardziej przekonujących świadectw lektury. Człowiek idealny zmierza do samodzielnego myślenia i rozpoznawania swego miejsca w świecie, bez determinanty etnicznej i socjalnej. Również miłość w przypadku człowieka idealnego ma charakter odmienny od miłości właściwej historycznym czasom utworu Norwida, miłość Aleksandra do Zofii przypomina swym autentyzmem nowożytną relację uczuciową pomiędzy mężczyzną a kobietą, jej najważniejszą cechą jest przyznanie ukochanej osobie prawa do samodzielnego istnienia.

Taką koncepcją głównego bohatera utworu wniósł Fieguth do badań nad Quidamem wiele nowego spojrzenia, przeciwstawiając się często wyrażanym przekonaniom o przeciętności tej postaci, jakiejś jej anonimowości, do której przyczyniła się semantyka wyrazu quidam, zwodnicza dla czytelników, będąca częścią tekstowej pułapki zastawionej przez autora na tych, którzy czytają powierzchownie, jednowymiarowo, na zasadzie percepcyjnych przyzwyczajeń do obowiązujących w połowie dziewiętnastego wieku konwencji literackich. Niemiecki slawista wykorzystuje konwencję tradycyjnej powieści edukacyjnej Bildungsroman, aby wytłumaczyć ów cały proces zmierzania przez głównego bohatera do stanu idealnego, ale też zgodnie ze swoim rozumieniem „,poezji w fazie krytycznej” niczego nie upraszcza. Komplikuje obraz Aleksandra, gdy podejmuje wątek autobiograficzny utworu, wskazując na symboliczne utożsamienie autora i bohatera, przy czym istotna jest w tej paraleli cezura śmierci bohatera, którą można uznać za symboliczną śmierć autora.

Z pewnością istotnym rozszerzeniem dotychczasowych ustaleń jest także wyczerpujące omówienie wątku powstania żydowskiego (132-134 n.e.) w poemacie, co przybliża warstwę historyczną utworu Norwida. Fieguth nie czyta go jednak z kompetencją archeologa, raczej, odtwarzając położenie Żydów w Cesarstwie Rzymskim, zastanawia się nad kształtowaniem stosunków między Żydami a nowoczesną cywilizacją Europy. Interesuje go zmieszanie czasu w poemacie, chodzi nie tylko o literackie konwencje czasu - w powieści, noweli i epopei. Cho-

31 R. FiEguth, Zaproszenie do „, Quidama”, s. 115. 
dzi również o wpływ typologicznej alegorezy w piśmiennictwie wczesnochrześcijańskim II wieku n.e. na alegoryczną koncepcję narracji w Quidamie. I chodzi o współdziałanie tych różnych żywiołów czasu, a raczej brak tego współdziałania, celowo wywoływane zakłócenia w strukturze narracji:

Nową strukturę narracyjną Quidama, stworzoną z różnych elementów gatunkowych i uszkodzoną poprzez podzielenie na części materiału zdarzeniowego, charakteryzuje hierarchia ruchoma, dynamiczna - drobiazg może okazać się nagle bardzo ważny, a coś z zasady bardzo doniosłego jako raczej drugorzędne ${ }^{32}$.

Fieguth łączy ważne dla poezji Norwida pojęcie ruiny z alegorezą czasu, czas zrujnowany epoki Hadriana i dziewiętnastowiecznej epoki Norwida odsłania (dziury w czasie) czas sakralny, a także bezczas wieczności. Pojęcie alegorezy czasu, którym badacz posługuje się konsekwentnie pozwala mu rozpatrywać kwestie chrześcijańskiej interpretacji dziejów w poemacie w perspektywie literaturoznawczej. Niemiecki slawista wskazuje na związki Quidama z tradycją biblijną poprzez odwołania do retoryki i noematyki, a krąg refleksji hermeneutycznej wyznacza horyzont światopoglądowych dociekań, wolnych od jakichkolwiek doktrynalnych rozstrzygnięć. W przypadku Norwida - poety niewątpliwie religijnego, ten rodzaj metodologicznej niezależności badacza pozwala na zachowanie dystansu wobec ideologicznych uroszczeń, które w obcowaniu z autorem Quidama zdarzają się w polskim stanie badań.

Nacisk, który kładzie Fieguth na znaczenie alegorii w poemacie ułatwia też wskazanie tych pól nawiązań do tradycji literatury dawnej, które umożliwiają poecie ogłoszenie programu nowego klasycyzmu. Badacz pisze o „ukąszeniu klasycznym" Norwida, które

piętnuje jego wyobraźnię, jego sposób myślenia i argumentacji, i co przenika aż jego składnię [...], nie mówiąc o uniwersum jego form literackich. Dotyczy to bogactwa jego nawiązań do starożytności, ale też do nowożytnych adaptacji form i wątków antycznych, w tym również do rodzimego klasycyzmu oświeceniowego. Jest to u Norwida zjawisko głębsze i bardziej charakterystyczne niż u innych wybitnych polskich autorów doby poklasycystycznej. Dla jego współczesnego funkcjonowania jako klasyka oznacza to, że Norwid bardziej niż pozostali wielcy poeci stulecia jest nosicielem rozległej twórczej pamięci kulturowej ${ }^{33}$.

Dla mnie, jako badacza poezji Norwida, szczególnie bliski jest ów ciąg myślowy zakładający wzajemną implikację pomiędzy następującymi cechami tej poezji: predylekcją poety do alegorii, deklaracją nowego klasycyzmu i szczegól-

\footnotetext{
32 Tamże, s. 133.

33 Tamże, s. 206-207.
} 
ną rolą pamięci kulturowej. Pisałem przy okazji omawiania tej wzajemnej implikacji o tym, że zwrot do alegorii w twórczości autora Quidama sprzeciwia się powszechnie przyjętej opinii o teleologii literatury dziewiętnastego wieku ${ }^{34}$. Można by powiedzieć, trawestując Hansa Gadamera ${ }^{35}$, że w poezji Norwida dokonuje się rehabilitacja alegorii. I w ślad za tym filozofem poddać w wątpliwość trwałość fundamentu dziewiętnastowiecznej estetyki, która tworzyła nieskrępowaną wolność symbolicznej działalności umysłu. Wydaje się, że Rolf Fieguth byłby bliski takiej konstatacji. W jego analizach symbolizm, podobnie jak alegoria współtworzy Norwidowski klasycyzm, a fragmenty książki poświęcone symbolicznym przedstawieniom w Quidamie są połączone z refleksją o pomysłach i reminiscencjach malarskich poematu. Za niezwykle oryginalne uznaję te konstatacje, które sytuują klasycyzm poety niekonkurencyjnie wobec estetyk romantycznych, takie pojęcia przywoływane przez Fiegutha jak: eklektyzm, hybryda i synkretyzm, każą nam sądzić, że dziedzictwo romantycznej młodości Norwida stanowi istotną komponentę postulowanego klasycyzmu.

Uważam też za trafne i inspirujące założenie czytania Quidama jako części składowej całego tomu lipskiego Poezji Norwida, zwłaszcza w kontekście nawiązań do pozostałych utworów tego zbioru, jak i ich nawiązań do antycznych motywów w twórczości Słowackiego i Krasińskiego, teza o klasycyzmie jako nowym programie poetyckim tego zbioru, broni się przekonująco.

Gdybym miał wskazać na to, co różni studia dotyczące Quidama od wcześniejszych publikacji ich autora na temat Vade-mecum, to zwróciłbym uwagę przede wszystkim na to, że studia te wyrosły z stałej i trwałej obecności Rolfa Fiegutha w polskim kręgu badań nad Norwidem. Jako badacz Vade-mecum przychodził do nas ze swojego slawistycznego świata koncepcji metodologicznych i obserwacji czynionych w małym jeszcze związku z polonistycznym krwiobiegiem naukowym. Quidama zaś czytał razem z nami, brał udział w pamiętnej konferencji na temat tego poemat, zorganizowanej w 2007 roku w Rzymie, w 150-lecie powstanie tego utworu. W 2008 roku współorganizował, wraz z małżonką Hildą Fieguth, poznańską konferencję „Norwid - artysta” ${ }^{36}$, podczas której przedstawił pierwszy rzut swoich szkiców o symbolizmie i obrazach Norwi-

${ }^{34}$ K. TrYbuś, Pamięć romantyzmu. Studia nie tylko z przeszłości, Poznań 2013, s. 178-193.

35 H. G. Gadamer, Prawda i metoda. Zarys hermeneutyki filozoficznej, przeł. B. Baran, Kraków 1993, s. 104.

${ }^{36}$ Zob. R. FiEGUTH, Karykaturalność, erotyzm, idealizacja. Kilka uwag o wybranych szkicach i rysunkach Norwida (w luźnym nawiazaniu do ,Quidama”), w: Norwid-artysta. W 125. Rocznice śmierci poety, red. K. Trybuś, W. Ratajczak, Z. Dambek, Poznań 2008, s. 11-26. Do monografii o Quidamie autor włączył także zmodyfikowany przedruk swojego artykułu Symbolizmy w ,Quidamie”, opublikowanego w książce Symbol w dziele Norwida, red. W. Rzońca, Warszawa 20011, s. 85-100. 
da, które później weszły do monografii o Quidamie. Tak ważna dla tej monografii teza o klasycyzmie Norwida kształtowała się długo i wiele zawdzięcza udziałowi w szerszym projekcie badań nad europejskimi klasycyzmami dziewiętnastego wieku ${ }^{37}$. A wszystko to działo się w okresie nieprzerwanej fascynacji innymi twórcami literatury polskiej - przede wszystkim Kniaźninem i Miłoszem, którym Fieguth poświęcił osobne publikacje książkowe ${ }^{38}$, przygotowywane długo, w oparciu o udział w konferencjach i seminariach na przestrzeni wielu lat. Książkę Zaproszenie do Quidama Rolf Fieguth napisał od początku do końca po polsku, znakomicie projektując właściwą, moim zdaniem, dykcję dla mówienia o czasie cywilizacyjnego kryzysu, o którym opowiada utwór Norwida. Jest to książka niezwykła, bo uwolniona od nadmiaru pojęciowego aparatu, stwarzająca, swym pełnym pisarskiego powabu stylem, rzeczywistą zachętę do czytania jednego z najtrudniejszych utworów poety.

\section{„ŁAGODNE PRAWO”}

Rolf Fieguth nie zamyka swych badań nad Norwidem, opublikowane rozprawy podsumowują jego refleksję nad twórczością poety, ale mają też swą dalszą kontynuację. Często odbywa się to poprzez dopowiedzenie tezy, zaznaczenie akcentu, czy też ogłoszenia czegoś na kształt glosy do wcześniejszych ustaleń. Taki charakter glosy ma wystąpienie prof. Fiegutha z okazji przyznania mu „Medalu za rozpowszechnienie wiedzy o Cyprianie Norwidzie" na KUL-u 16 X 2017 roku. Mówił wtedy o chrześcijaństwie w Quidamie:

Norwid uważał pojawienie się Chrystusa na ziemi za punkt wyjścia cichej, powolnie postępującej rewolucji, która nosi ze sobą długą prehistorię w postaci kultury greckiej i judaizmu, trudną aktualność wielokulturowej cywilizacji rzymskiej czasów imperatora Adriana, i daleką perspektywę przyszłości sięgającej (nie tylko) do dziewiętnastego wieku.

$[\ldots]$

W Norwidowskiej wizji procesu wywołanego przez rewolucję chrystusową, a także w narracji Quidama, współistnieją ze sobą dwa aspekty: Aspekt „łagodnego prawa” i aspekt drastycz-

${ }^{37}$ Zob. publikacje R. FIEGUTHA dotyczące różnych klasycyzmów XIX wieku w książce Klasycyzm. Estetyka - Doktryna literacka - Antropologia. red. K. Meller, Warszawa 2009, s. 345-374, 563-584.

38 Zob. R. Fieguth, ,, Sobie wielki”. O pięciu zbiorach lirycznych Franciszka Dionizego Kniaźnina; R. FIEGUTH, Rzeki, przestrzenie, rytm. Marginalia o poezji Czesława Miłosza, Poznań 2020. 
nych zdarzeń. Termin „,łagodnego prawa” (das sanfte Gesetz) zapożyczam tu od Adalberta Stiftera $^{39}$ zachęcony przez Christiana Zehndera.

W myśl „łagodnego prawa” działa ów proces w sposób dyskretny, najczęściej na dalekich peryferiach świadomości zbiorowej i indywidualnej, poza jasną wiedzą ludzi i ludzkości, ale niepowstrzymanie jak podwyższenie poziomu wód gruntowych.

$[\ldots]$

Cicha rewolucja chrystusowa wpływa na prywatne reakcje i losy każdej z osób pierwszoplanowych poematu bez ich jawnej wiedzy, przy czym w bardzo różnicowany sposób. Wszyscy lub prawie wszyscy ludzie opisani w Quidamie są w jakiejś mierze świadkami, albo nawet kapłanami tej rewolucji, w większości „bezwiednymi i niedojrzałymi“ (zob. wiersz z Vade-mecum - XV. Sfinks). Nie wiedząc o tym, czy nawet zaprzeczając temu - noszą sobą, na sobie czy w sobie w różnym stopniu ślady owej cichej rewolucji "40.

Czy ten wyraźny akcent postawiony nad biedermeierowską paralelą Quidama jest reinterpretacją koncepcji chrześcijaństwa Norwida? Wydaje się, że wywodom Fiegutha nie towarzyszy intencja włączenia rzymskiego poematu do antologii literatury biedermeierowskiej, chociaż to właśnie Stifter ze swoim ,łagodnym prawem" pozostaje głównym wyznacznikiem biedermeierowskiego stylu ${ }^{41}$. Odbieram te uwagi o Quidamie jako potrzebę zaznaczenia doktrynalnej niejednoznaczności chrześcijańskiej wizji świata w twórczości Norwida, zarazem potrzebę podkreślenia otwartego charakteru procesu chrystianizacji, pojętego jako akt spełniający się w ciągłym i nieskończonym procesie.

Podobne treści zawierają niedawno opublikowane rozważania o (wspomnianym w przytoczonej wypowiedzi) wierszu Sfinks [II], który wydaje się bardzo ważny dla Fiegutha:

Wybrałem ten wiersz, gdyż daje mi do myślenia od wielu lat, przede wszystkim ze względu na jego sentencję centralną: »Człowiek? jest to kapłan bez-wiedny/I niedojrzały...«. To ona mi towarzyszyła w moich interpretacjach Zdań i uwag Mickiewicza, Quidama Norwida i Drugiej przestrzeni Czesława Miłosza ${ }^{42}$.

39 Adalbert Stifter, wybitny austriacki pisarz (1805-1868). Koncepcję „łagodnego prawa”, rządzącego nad światem niezależnie od inicjatyw człowieka, wyłożył w przedmowie do dwutomowego zbioru szkiców w prozie Bunte Steine. Ein Festgeschenk [Kolorowe kamienie. Dar na uroczystość], Pest 1853.

${ }^{40}$ R. Fieguth, Chrześcijaństwo dla wszystkich. Parę słów nt. „, Quidama” C. Norwida, „Studia Norwidiana" 37: 2019, s. 281-284.

${ }^{41}$ Zob. na ten temat Spory o biedermeier. Wybór, wstęp i opracowanie J. Kubiak, Poznań 2006 (tu zwłaszcza: J. KuBIAK, Wstep. Adalbert Stifter $i$, łagodne prawo”), s. 7- 63.

${ }^{42}$ R. FIEGUTH, Pomysty o recytacji wiersza ,Sfinks [II], w: Cyprian Norwid. Osobność, oprac. E. Kącka, Kraków 2018, s. 115. 
To znaczący komunikat, potwierdza otwarte, a w każdym bądź razie otwierające różne pod względem światopoglądowym przestrzenie poetyckiej metafizyki, przesłanie wiersza Sfinks [II]. Interpretator dodaje:

Sentencja wędrowca zawiera prowokację dla wierzących, półwierzących i niewierzących. Człowiek ma być w istocie kapłanem, czyli nosicielem prawdy bożej. Ale on nic o tym nie wie, jest »bez-wiedny«. W dodatku jest »niedojrzały« - czyli »nie dojrzewa do swego kapłaństwa«, ale też w zasadzie go »nie doziera«, jest nań ślepy. Jednym słowem człowiek w takim ujęciu przy całym tragizmie swej egzystencji ma coś wyraźnie śmiesznego w sobie ${ }^{43}$.

Dotyka tu Fieguth problemu, który rozwija w swoim komentarzu do wiersza Ogólniki z tomu Vade-mecum, w trakcie konferencji, którą dedykowali mu poznańscy poloniści, z okazji uroczystości nadania temu wybitnemu niemieckiemu poloniście tytułu doktora honorowego Uniwersytetu im. Adama Mickiewicza ${ }^{44}$. Koncentruje tu uwagę na elementach ludycznej lekkości, sokratycznej parodii cudzej mowy i cudzego myślenia oraz uśmiechu poety kierowanego w stronę własną i czytelników. Fragment tego komentarza do wiersza Ogólniki niech posłuży za Fieguthowe credo jego badań nad Norwidem:

Młodzież szkolna grzecznie czyta ten utwór, starając się włożyć weń całą tragiczną powagę emanującą i z cyklu Vade-mecum, i z losów poety, i z losów ojczyzny. Ja chciałbym dziś zwrócić uwagę na lżejsze strony tego utworu.

Ogólniki noszą swą nazwę nie na darmo - jest w nich pierwiastek ludyczności i gry z czytelnikiem i czytelniczką, a żadne z trzech haseł ogólnikowych wieńczących każdą ze strof nie pretenduje do prawdy absolutnej ${ }^{45}$.

\section{BIBLIOGRAFIA}

BIEŃKowska E., Norwid-Nietzsche. Dwie twarze losu, Warszawa 1975.

Fieguth R., Poezja w fazie krytycznej. Cykl wierszy Cypriana Norwida „,Vade-mecum”, ,Studia Norwidiana" 3-4: 1985-1986, s. 13-55.

FIEGUTH R., Verzweigungen. Zyklische und assoziattive Kompositionsformen bei Adam Mickiewicz, Freiborg Schweiz 1998.

Fieguth R., Poezja $w$ fazie krytycznej $i$ inne studia z literatury polskiej, Izabelin 2000, ss. 327.

43 Tamże, s. 119.

${ }^{44}$ Konferencja odbyła się w Poznaniu, w dn. 24-25 X 2017 r.

${ }^{45}$ R. Fieguth, O „Ogólnikach” Cypriana Norwida, w: Wielkie wiersze - nowe lektury, red. K. Trybuś, Poznań 2019, s. 20. 
FIEGUTH R., Rozpierzchłe gałazki. Cykliczne i skojarzeniowe formy w twórczości Adama Mickiewicza, przeł. M. Zieliński, Warszawa 2002.

FIEGUTH R., Karykaturalność, erotyzm, idealizacja. Kilka uwag o wybranych szkicach i rysunkach Norwida (w luźnym nawiazaniu do „, Quidama”), w: Norwid-artysta. W 125. Rocznicę śmierci poety, red. K. Trybuś, W. Ratajczak, Z. Dambek, Poznań 2008, s. 11-26.

FIEGUTH R., Klasycyzm. Estetyka - Doktryna literacka - Antropologia. red. K. Meller, Warszawa 2009, s. 345-374, 563-584.

Fieguth R., „Vade-mecum” Cypriana Norwida w kontekście Wiktora Hugo i Charles'a Baudelaire'a, w: Gombrowicz z niemiecka gęba i inne studia komparatystyczne, Poznań 2011, s. 246-261.

Fieguth R., Zaproszenie do „Quidama”. Portret poematu Cypriana Norwida, Kraków 2014.

Fieguth R., ,, Sobie wielki”. O pięciu zbiorach lirycznych Franciszka Dionizego Kniaźnina, Warszawa 2018.

Fieguth R., Pomysty o recytacji wiersza „,Sfinks [II], w: Cyprian Norwid. Osobność, oprac. E Kącka, Kraków 2018, s. 115-120.

Fieguth R., Chrześcijaństwo dla wszystkich. Parę słów nt. „, Quidama” C. Norwida, „Studia Norwidiana" 2019, nr 37, s. 281-284.

Fieguth R., Rzeki, przestrzenie, rytm. Marginalia o poezji Czesława Miłosza, Poznań 2020.

GŁowIŃski M., Norwida wiersze-przypowieści, w: Cyprian Norwid. W 150-lecie urodzin poety. Materiały z konferencji naukowej. 23-24 września 1971, red. M. Żmigrodzka, Warszawa 1973, s. 72-109.

GŁowIŃski M., Gorzkie kalambury. O „Purytanizmie” Cypriana Norwida, „Studia Norwidiana" 2: 1984, s. 63-74.

JAKobson R., Czułość" Cypriana Norwida, w: For Wiktor Weintraub. Essays in Polish Literature, Language and History. Presented on the Occasion of His 65th Birthday, The Hague 1975, s. 227-237.

ŁAPIŃSKi Z., Norwid, wyd. II, Kraków 1984.

STEFANOWSKA Z., Norwid - pisarz wieku kupieckiego i przemystowego, w: Literatura, komparatystyka, folklor. Księga pamiątkowa poświęcona Julianowi Krzyżanowskiemu, red. M. Bokszczanin, S. Frybes i E. Jankowski, Warszawa 1968, s. 423-460.

Trojanowicz Z., Rzecz o młodości Norwida, Poznań 1968.

TrYbuś K., Pamięć romantyzmu. Studia nie tylko z przeszłości, Poznań 2013.

Wyka K., Pokolenia literackie, przedmowa H. Markiewicz, Kraków 1977, s. 249-306.

VInCENZ A., Norwid po niemiecku, „Studia Norwidiana” 2: 1984, s. 84-90.

\section{NORWID W BADANIACH ROLFA FIEGUTHA}

\section{Streszczenie}

Autor tego artykułu stara się przedstawić badania Rolfa Fiegutha, poświęcone twórczości Norwida, koncentrując uwagę przede wszystkim na studiach wybitnego niemieckiego slawisty o cyklu poetyckim Vade-mecum i poemacie Quidam. W pierwszej kolejności rekonstrukcji tu podlegają założenia i ustalenia studium o ,poezji w fazie krytycznej” z 1985 roku, a także późniejszy szkic o komparatystycznych kontekstach cyklu wierszy Norwida z 2005 roku 
(opublikowany po polsku w 2011 r.). Wiele uwagi w tej części artykułu poświęca się dokonanej przez Fiegutha analizie zakłóceń w poezji autora Vade-mecum na różnych poziomach organizacji wiersza. Uwagi te dopełnia charakterystyka sformułowanej przez Fiegutha koncepcji komparatystycznej „konfrontacji międzykulturowej”, która wykracza poza dualne ujęcia twórczości literackiej, odsłaniając zawsze szeroki, europejski kontekst spotkań poetów i ich tekstów uczestniczących w procesie przenikania się kultur narodowych.

Druga część artykułu poświęcona jest książce Rolfa Fiegutha Zaproszenie do „, Quidama”. Portret poematu Cypriana Norwida z 2014 roku. Refleksja o tej publikacji dotyczy nie tylko szczegółowych ustaleń jej autora na temat poematu Norwida, ale także przyjętych przez niego założeń metodologicznych, które pozwoliły odświeżyć dawny gatunek historii literatury, jakim była monografia typu ,autor i dzieło”. Szerzej spośród zagadnień przedstawionych w tej książce autor artykułu omawia trudności towarzyszące lekturze Quidama i problematykę Norwidowskiego klasycyzmu.

W trzeciej części artykułu zwraca się uwagę na pojedyncze glosy Rolfa Fiegutha do jego badań nad Norwidem, pochodzące z lat ostatnich $(2017,2018,2020)$. Całość artykułu jest podsumowaniem ponad trzydziestoletnich studiów Rolfa Fiegutha nad najważniejszymi poetyckimi dokonaniami polskiego poety.

Słowa kluczowe: Cyprian Norwid, polski romantyzm, poezja europejska, cykl poetycki, komparatystyka

\title{
NORWID IN STUDIES BY ROLF FIEGUTH
}

\begin{abstract}
This article aims discusses Rolf Fieguth's studies of works by Norwid, focusing primarily on the German Slavist's interpretations of the cycle Vade-mecum and the long poem Quidam. The first work reconstructed here, along with its assumptions and conclusions, is Fieguth's 1985 study on "poetry in a critical phase"and the second is the 2005 essay on the comparative contexts of Norwid's famous cycle (the latter was published in Polish in 2011). A lot of room is devoted in this section to Fieguth's analysis of distortions introduced by Norwid at various levels of the poem's organization. These remarks are complemented with an account of Fieguth's comparatist conceptof "cultural confrontation," which goes beyond dualistic accounts of literary creativity, revealing the invariably broad, European context of meetings between poets and texts, facilitated by the process of national cultures permeating each other. The second part of the article is devoted to Fieguth's 2014 book Zaproszenie do „, Quidama”. Portret poematu Cypriana Norwida [An invitation to Quidam. A portrait of Cyprian Norwid's long poem]. Reflections on this publication concern not only its detailed findings about Norwid's long poem but also the critic's methodological assumptions, which have helped him to update the long-standing genre in the history of literature, namely the "author and his particular work" type of monograph. Among the issues addressed in the book, the article discusses, in particular, the difficulties accompanying interpretations of Quidamand the question of Norwid's classicism. The third part of the article draws attention to Fieguth's remarks onNorwid made in recent years $(2017,2018,2020)$. The article thus summarizes Rolf Fieguth's thirty years of research on the most important poetic achievements of the Polish poet.
\end{abstract}

Translated by Grzegorz Czemiel 
Key words: Cyprian Norwid, Polish Romanticism, European poetry, poetic cycles, comparative studies

KRZYSZTOF TRYBUŚ - prof. dr hab., historyk literatury, zajmuje się literaturą polskiego romantyzmu, głównie twórczości Norwida i Mickiewicza, a także problematyką tradycji literackiej i pamięci.

Jest autorem książek: Epopeja w twórczości Cypriana Norwida (Wrocław 1993), Stary poeta. Studia o Norwidzie (Poznań 2000), Pamięć romantyzmu. Studia nie tylko z przeszłości (Poznań 2011), Zima romantyków. Szkice o literaturze i pamięć, Poznań 2017, współredaktorem wielu tomów rozpraw i szkiców; członek redakcji „Pamiętnika Literackiego”. 